\title{
KONTRIBUSI VIRTUAL LABORATORY \\ PADA PEMBELAJARAN GUIDED-INQUIRY \\ MATERI LARUTAN PENYANGGA TERHADAP HASIL BELAJAR DAN KETERAMPILAN BERPIKIR KRITIS SISWA
}

\author{
Nafilatul Arfa ${ }^{1}$, Harjono ${ }^{2}$, Woro Sumarni ${ }^{3}$, Murbangun Nuswowati ${ }^{4}$ \\ 1,2,3,4 Jurusan Kimia FMIPA Universitas Negeri Semarang \\ Jl. Raya Sekaran, Sekaran, Kec. Gunungpati, Kota Semarang, Jawa Tengah 50229
}

\begin{abstract}
This study aims to see all the major contributions to virtual laboratory applications in learning directed at student learning outcomes and Critical Thinking Skills (CBC). The research design used a pre-test post-test control group design. The research was conducted at SMA Negeri 1 Kedungwuni. The population of this study were all students of class XI MIPA for the 2018/2019 academic year, with the research sample, namely XI MIPA 2 as the experimental class and XI MIPA 3 as the control class. The experimental class was carried out with guided-inquiry learning assisted by a virtual laboratory accompanied by demonstrations, the control class was carried out with guided inquiry learning with the demonstration method. Both classes conducted real experiments after giving treatment. Methods of data collection through a twotier form test, and observation. The results showed that the average learning outcomes and $\mathrm{CBC}$ in the experimental class were better than the control class and it was found that the virtual laboratory in guided-inquiry learning contributed $14.57 \%$ to learning outcomes and $20.54 \%$ contribution to critical thinking skills.
\end{abstract}

Keywords: Learning Outcomes, Critical Thinking Skills, Guided-Inquiry Learning, Virtual Laboratory

\begin{abstract}
Abstrak
Penelitian ini bertujuan untuk mengetahui seberapa besar kontribusi aplikasi virtual laboratory pada pembelajaran guided-inquiry terhadap hasil belajar dan Keterampilan Berpikir Kritis (KBK) siswa. Desain penelitian menggunakan pre-test post-test control group design. Penelitian dilakukan di SMA Negeri 1 Kedungwuni. Populasi penelitian ini adalah seluruh siswa kelas XI MIPA tahun ajaran 2018/2019, dengan sampel penelitian yaitu XI MIPA 2 sebagai kelas eksperimen dan XI MIPA 3 sebagai kelas kontrol. Kelas eksperimen dilakukan pembelajaran guided-inquiry berbantuan virtual laboratory disertai demonstrasi, kelas kontrol dilakukan pembelajaran dengan guided-inquiry dengan metode demonstrasi. Kedua kelas melakukan eksperimen riil setelah pemberian perlakuan. Metode pengumpulan data melalui tes bentuk two-tier dan observasi. Hasil penelitian menunjukkan ratarata hasil belajar dan KBK kelas eksperimen lebih baik dari kelas kontrol dan
\end{abstract}

Universitas Negeri Semarang

Email: nafilatul.arfa@gmail.com
(C)2020 Universitas Islam Negeri Walisongo

ISSN: 2088-7868, e-ISSN 2502-5708 
diperoleh bahwa virtual laboratory pada pembelajaran guided-inquiry berkontribusi terhadap hasil belajar sebesar $14,57 \%$ dan kontribusi terhadap keterampilan berpikir kritis sebesar 20,54\%.

Kata kunci: Hasil Belajar, Keterampilan Berpikir Kritis, Pembelajaran Guided-Inquiry, Virtual Laboratory

\section{PENDAHULUAN}

Berbagai perubahan dalam abad 21 menghadapkan pendidikan Indonesia dengan sejumlah tantangan. Menurut Abidin (2014) untuk menghadapi tantangan abad ke-21 ada empat kompetensi belajar yang harus dikuasai yakni, (1) kemampuan pemahaman yang tinggi, (2) kemampuan berkolaborasi dan berkomunikasi, (3) kemampuan berpikir kreatif, serta (4) kemampuan berpikir kritis. Selain itu, Tuntutan menjadi guru yang inovatif semakin meningkat dengan munculnya kurikulum 2013 yang mengutamakan sikap, pengetahuan dan keterampilan. Guru sebagai fasilitator dalam pembelajaran harusnya tidak hanya berpangku tangan menghadapi tantangan tersebut, guru harus mampu mengakomodasi kebutuhan siswa dalam pembelajaran. Pemanfaatan media pembelajaran dan penggunaan model pembelajaran dapat digunakan sebagai sumber belajar yang optimal dalam meningkatkan hasil belajar siswa. Selain itu penggunaan media juga diperlukan untuk membuat konsep yang sifatnya abstrak menjadi lebih konkret. Penggunaan media pembelajaran dapat membangkitkan minat, motivasi, rangsangan dalam kegiatan belajar, dan membawa pengaruh psikologis terhadap pembelajaran. Penggunaan media pembelajaran akan sangat membantu keefektifan proses pembelajaran dan penyampaian peran dan isi materi pembelajaran (Falahudin $e t$ al, 2014).

Efektivitas proses pembelajaran sudah semestinya terjadi dalam pembelajaran agar meningkatkan minat belajar siswa. Akan tetapi berdasarkan hasil wawancara dan studi literatur diperoleh bahwa masih banyak siswa yang mengalami kesulitan dalam memahami materi kimia yang mengakibatkan rendahnya hasil belajar siswa. Hal tersebut ditunjukkan oleh rekap nilai PAS semester gasal siswa kelas XI MIPA tahun ajaran $2018 / 2019$ yang belum mencapai kriteria ketuntasan minimal $(\mathrm{KKM}=75)$ dengan ratarata 54,06 dan persentase ketuntasan kurang dari 75\% yaitu 17,75\%. Pembelajaran juga lebih didominasi oleh guru sehingga siswa cenderung hanya menerima apa yang disampaikan oleh guru. Keadaan ini berimbas pada keterampilan berpikir kritis siswa yang rendah. Wasitohadi et al. (2014) mengungkapkan agar siswa memiliki keterampilan 
berpikir kritis perlu diadakan peningkatan kualitas pembelajaran dengan mengubah orientasi pembelajaran yang semula berpusat pada guru beralih berpusat pada siswa yang bertujuan memperbaiki mutu pendidikan dari segi proses maupun hasil. Pembelajaran yang hanya berpusat pada guru juga mengakibatkan kurangnya minat dalam mengikuti pembelajaran sehingga hasil belajar afektif siswa rendah. Kegiatan praktikum juga jarang dilakukan oleh guru terutama pada materi larutan penyangga dikarenakan keterbatasan waktu yang dimiliki guru. Kurangnya pelaksanaan praktikum mengakibatkan banyak siswa yang kurang terampil ketika melaksanakan praktikum sehingga psikomotorik siswa menjadi rendah.

Kegiatan praktikum di laboratorium sangat diperlukan dalam pembelajaran kimia karena kimia merupakan salah satu pembelajaran bidang sains yang pada dasarnya menuntut siswa untuk dapat mengaitkan teori dengan fenomena kehidupan sehingga siswa dapat melakukan penemuan dan pemecahan masalah sehari-hari (Widyaningrum et $a l ., 2014)$. Kegiatan praktikum dapat membantu pemahaman siswa terhadap materi yang diajarkan di kelas. Selain itu, keterampilan berpikir siswa juga terlatih dengan membandingkan teori yang diperoleh dengan hasil praktikum. Pemanfaatan media pembelajaran seperti penggunaan aplikasi virtual laboratory dapat dijadikan solusi atas permasalahan dalam pelaksanaan praktikum karena virtual laboratory dapat digunakan kapan saja dan dimana saja sehingga eksperimen dapat dilaksanakan secara kontinyu (Simbolon \& Sahyar, 2015).

Berdasarkan permasalahan tersebut siswa perlu dilatih dengan suatu model pembelajaran yang menjadikan siswa sebagai subjek belajar yang aktif dan dapat mengembangkan keterampilan berpikir dalam memecahkan masalah melalui suatu eksperimen sehingga siswa mampu menemukan konsep sendiri. Salah satu model pembelajaran yang efektif untuk menunjang kegiatan pembelajaran tersebut adalah pembelajaran berbasis inkuiri (Inquiry Based Learning). Pembelajaran berbasis inkuiri mendorong siswa untuk belajar melalui keterlibatan aktif dalam menemukan konsep dan prinsip mereka sendiri dengan guru sebagai pendorong siswa agar memiliki pengalaman dengan melakukan percobaan untuk menemukan prinsip tersebut (Suhada, 2017). Hasil penelitian dengan penerapan media pembelajaran dengan eksperimen virtual berbasis inkuiri mampu meningkatkan hasil belajar siswa (Oktavianti \& Arief, 2016). Keterampilan berpikir kritis siswa meningkat pada kelas eksperimen yang menerapkan 
model guided inquiry berbantuan e-modul (Budiarti et al., 2016). Beberapa penelitian tersebut dapat menggambarkan bahwa penerapan pembelajaran inkuiri terbimbing berbantuan virtual laboratory mampu meningkatkan keterampilan berpikir kritis dan hasil belajar siswa.

Kegiatan pembelajaran kimia khususnya pokok materi larutan penyangga pada indikator menganalisis larutan penyangga dan bukan penyangga serta indikator pembuatan larutan penyangga dengan $\mathrm{pH}$ tertentu melalui percobaan hanya dilakukan melalui pemberian teori kepada siswa tanpa adanya kegiatan praktikum. Berdasarkan data hasil ujian nasional (UN) 2019 jenjang SMA tingkat provinsi Jawa Tengah pada materi larutan penyangga dengan indikator menganalisis cara/ prosedur/ kondisi dalam suatu eksperimen pembuatan larutan penyangga, diperoleh hasil dengan daya serapnya 33,10\%, dan di SMA Negeri 1 Kedungwuni menunjukkan daya serapnya 26,09\% pada indikator tersebut (Puspendik, 2019).

Berdasarkan analisis masalah di atas, peneliti berpendapat perlu dilakukan inovasi pembelajaran untuk materi larutan penyangga dengan pembelajaran berbasis inkuiri terbimbing berbantuan virtual laboratory yang diharapkan dapat meningkatkan hasil belajar dan keterampilan berpikir kritis siswa.

\section{METODE PENELITIAN}

Jenis penelitian yang dilaksanakan merupakan penelitian eksperimen dengan desain penelitian true experimental design berbentuk pre-test post-test control group design. Penelitian dilaksanakan di SMA N 1 Kedungwuni pada 15 Maret - 19 April 2019. Populasi pada penelitian ini adalah seluruh siswa kelas XI MIPA tahun ajaran 2018/2019 dengan sampel penelitian XI MIPA 2 sebagai kelas eksperimen dan XI MIPA 3 sebagai kelas kontrol. Kelas eksperimen dilakukan pembelajaran guided-inquiry dengan metode demonstrasi berbantuan virtual laboratory sebagai penunjang eksperimen riil. Kelas kontrol dilakukan pembelajaran guided-inquiry dengan metode demonstrasi oleh guru sebagai penunjang eksperimen riil.

Metode pengumpulan data yang digunakan adalah metode tes dan metode observasi. Instrumen penelitian menggunakan soal tes bentuk two tier dan lembar observasi. Teknik analisis data pada tahap awal dilakukan untuk memilih sampel melalui uji normalitas dan uji homogenitas populasi, analisis tahap akhir dilakukan untuk 
menganalisis nilai hasil belajar dan skor keterampilan berpikir kritis yang meliputi uji normalitas, uji kesamaan varians, uji dua rata-rata (uji satu pihak kanan), uji pengaruh antar variabel, dan penentuan koefisien determinasi, analisis deskriptif hasil belajar afektif dan psikomotorik.

\section{HASIL DAN PEMBAHASAN}

Kegiatan pembelajaran diawali dengan pretest pada kelas eksperimen dan kelas kontrol yang bertujuan untuk mengetahui kemampuan awal dari hasil belajar kognitif dan keterampilan berpikir kritis siswa sebelum diberikan perlakuan. Pretest dianalisis menggunakan uji normalitas, uji kesamaan dua varian, dan uji dua rata-rata (uji dua pihak). Hasil analisis terhadap nilai pretest menunjukkan data berdistribusi normal, kedua kelas memiliki varians yang tidak berbeda, dan rata-rata nilai pretest hasil belajar kognitif kelas eksperimen sama dengan kelas kontrol.

Kedua kelas diberikan posttest setelah proses pembelajaran dilakukan untuk mengetahui hasil belajar kognitif dan keterampilan berpikir kritis siswa. Hasil posttest dianalisis menggunakan uji normalitas, uji kesamaan dua varian, uji dua rata-rata (uji satu pihak kanan), uji pengaruh antar variabel, dan penentuan koefisien determinasi. Hasil analisis terhadap nilai posttest menunjukkan data berdistribusi normal dan kedua kelas memiliki varians yang tidak berbeda dengan $F_{\text {hitung }}(1,4997)<F_{\text {tabel }}(2,1609)$, sehingga untuk uji dua rata-rata dapat menggunakan rumus t. Hasil uji dua rata-rata (uji satu pihak kanan) menunjukkan $t_{\text {hitung }}(4,637)>t_{\text {tabel }}(1,680)$, sehingga $\mathrm{H}_{0}$ ditolak, artinya rata-rata posttest hasil belajar kognitif kelas eksperimen lebih baik dari kelas kontrol. Hasil ini dapat disimpulkan bahwa penggunaan aplikasi virtual laboratory dapat mempengaruhi rata-rata nilai posttest siswa, sehingga kelas yang proses pembelajarannya menggunakan aplikasi virtual laboratory memiliki rata-rata nilai yang lebih tinggi. Hal tersebut sejalan dengan hasil penelitian Anisah, et al. (2013) hasil nilai rata-rata akhir pada kelas eksperimen yang menerapkan virtual laboratory pada proses belajar lebih tinggi dari kelas kontrol. Siswa yang menggunakan virtual laboratory lebih banyak menghasilkan jawaban benar (Harrison et al., 2009). Tüysüz (2010) menyimpulkan dalam penelitiannya bahwa aplikasi virtual laboratory dapat meningkatkan prestasi dan sikap siswa terhadap pembelajaran kimia. Nilai posttest selanjutnya dianalisis dengan uji pengaruh antar variabel, diperoleh koefisien korelasi biserial (rb) sebesar 0,382. 
Penentuan koefisien determinasi digunakan untuk menentukan besarnya kontribusi virtual laboratory terhadap hasil belajar kognitif dan diperoleh sebesar 14,57\%.

Hasil analisis terhadap hasil nilai posttest tersebut, menunjukkan bahwa virtual laboratory berkontribusi terhadap hasil belajar kognitif pada pembelajaran guidedinquiry. Hal tersebut sejalan dengan penelitian Simbolon \& Sahyar (2015) yang menghasilkan simpulan bahwa terdapat perbedaan yang signifikan hasil belajar siswa yang menggunakan model pembelajaran inkuiri terbimbing berbasis eksperimen riil dan laboratorium virtual dibanding dengan siswa yang diajar menggunakan model pembelajaran langsung.

Hasil belajar afektif diamati selama pembelajaran berlangsung melalui observasi. Hasil nilai rata-rata afektif kelas eksperimen memenuhi kriteria sangat baik dengan ratarata mencapai 39,04 dan hasil nilai rata-rata afektif kelas kontrol memenuhi kriteria baik dengan rata-rata nilai afektif mencapai 38,08. Perbandingan hasil observasi afektif antara kelas eksperimen dan kelas kontrol disajikan pada Tabel 1.

Tabel 1. Perbandingan hasil observasi afektif

\begin{tabular}{|c|c|c|c|c|c|}
\hline \multirow[b]{2}{*}{ Kelas } & \multicolumn{4}{|c|}{ Kategori } & \multirow[b]{2}{*}{$\begin{array}{c}\text { Jumlah } \\
\text { Siswa }\end{array}$} \\
\hline & $\begin{array}{l}\text { Sangat Baik } \\
\text { (A) }\end{array}$ & $\begin{array}{c}\text { Baik } \\
\text { (B) }\end{array}$ & $\begin{array}{c}\text { Cukup } \\
\text { (C) }\end{array}$ & $\begin{array}{l}\text { Kurang } \\
\text { (D) }\end{array}$ & \\
\hline Eksperimen (XI MIPA 2) & 13 & 15 & 0 & 0 & 28 \\
\hline Kontrol (XI MIPA 3) & 6 & 22 & 0 & 0 & 28 \\
\hline
\end{tabular}

Hasil pada Tabel 1 menunjukkan bahwa hasil belajar afektif kelas eksperimen lebih baik dari kelas kontrol. Kelas eksperimen mencapai 46,43\% siswa yang memenuhi kriteria skor sangat baik dan 53,57\% siswa yang memenuhi kriteria skor baik. Kelas kontrol mencapai $21,43 \%$ siswa yang memenuhi kriteria skor sangat baik dan 78,57\% siswa yang memenuhi kriteria skor baik. Hasil belajar afektif dalam penelitian ini terdapat tujuh aspek afektif yang diamati yaitu jujur, disiplin, tanggungjawab, rasa ingin tahu, kerjasama, sopan santun, dan percaya diri, yang setiap aspek memiliki indikatornya masing-masing. Perbandingan rata-rata skor tiap aspek afektif antara kelas eksperimen dan kelas kontrol disajikan pada Gambar 1. 


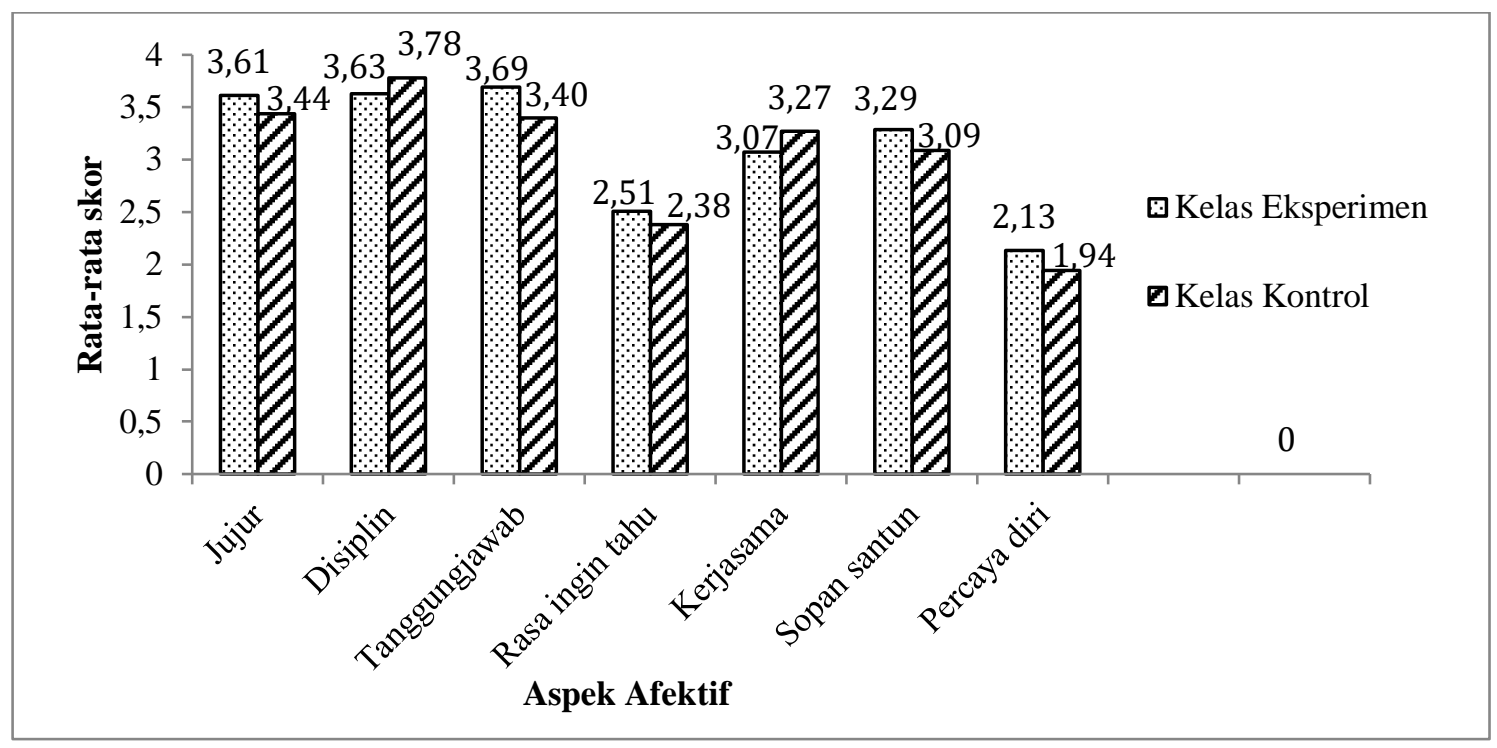

Gambar 1. Perbandingan rata-rata skor tiap aspek afektif

Berdasarkan Gambar 1 diketahui bahwa tidak semua skor aspek afektif kelas eksperimen lebih tinggi dari kelas, misalnya aspek disiplin dan aspek kerjasama. Aspek disiplin siswa kelas eksperimen maupun kelas kontrol dalam kategori sangat baik. Hal tersebut karena aturan sekolah yang mengharuskan siswanya berpakaian rapi dan lengkap. Apabila ada siswa yang melanggarnya maka akan mendapat teguran dari pihak sekolah. Namun, secara keseluruhan skor disiplin kelas kontrol lebih tinggi dari kelas eksperimen karena beberapa siswa kelas eksperimen dalam pembelajaran sering telat masuk. Hal tersebut karena pada kelas eksperimen jam pembelajaran kimia setelah istirahat. Skor aspek kerjasama kelas kontrol juga lebih tinggi dari kelas eksperimen. Hal tersebut karena kelas eksperimen sudah lebih mengerti langkah kerja dalam praktikum karena telah lebih dulu melakukan praktikum menggunakan virtual laboratory sehingga saat melakukan praktikum riil masing-masing siswa bekerja sendiri dalam kelompok. Siswa kelas kontrol cenderung sering bertanya dan bekerjasama dengan temannya karena belum sepenuhnya mengerti alur kerja praktikum.

Berdasarkan Tabel 1 dan Gambar 1 menunjukkan bahwa hasil belajar afektif kelas eksperimen lebih tinggi daripada kelas kontrol atau kelas yang menggunakan aplikasi virtual laboratory memiliki rata-rata hasil belajar afektif yang lebih tinggi daripada kelas yang tanpa virtual laboratory. Hasil ini sejalan dengan penelitian Așiksoy \& Islek (2017) bahwa penggunaan virtual laboratory memiliki efek positif terhadap sikap siswa selama pembelajaran. 
Hasil belajar psikomotorik diamati melalui observasi selama kegiatan praktikum berlangsung pada kelas eksperimen maupun kelas kontrol. Nilai rata-rata hasil belajar psikomotorik pada kelas eksperimen memenuhi kriteria sangat baik dengan rata-rata skor mencapai 36,11 dan rata-rata untuk kelas kontrol memenuhi kriteria baik dengan skor mencapai 34,82. Perbandingan hasil observasi psikomotorik antara kelas eksperimen dan kelas kontrol disajikan pada Tabel 2.

Tabel 2. Perbandingan hasil belajar psikomotorik

\begin{tabular}{|c|c|c|c|c|c|}
\hline \multirow[b]{2}{*}{ Kelas } & \multicolumn{4}{|c|}{ Kategori } & \multirow{2}{*}{$\begin{array}{c}\text { Jumlah } \\
\text { Siswa }\end{array}$} \\
\hline & $\begin{array}{l}\text { Sangat Baik } \\
\text { (A) }\end{array}$ & $\begin{array}{c}\text { Baik } \\
\text { (B) }\end{array}$ & $\begin{array}{c}\text { Cukup } \\
\text { (C) }\end{array}$ & $\begin{array}{c}\text { Kurang } \\
\text { (D) }\end{array}$ & \\
\hline Eksperimen (XI MIPA 2) & 15 & 13 & 0 & 0 & 28 \\
\hline Kontrol (XI MIPA 3) & 9 & 19 & 0 & 0 & 28 \\
\hline
\end{tabular}

Hasil pada Tabel 2 menunjukkan kelas eksperimen mencapai 53,57\% siswa dengan kategori sangat baik dan 46,43\% siswa dengan kategori baik. Kelas kontrol mencapai $32,14 \%$ siswa kategori sangat baik dan $67,86 \%$ siswa kategori baik. Uraian tersebut menunjukkan bahwa hasil belajar psikomotorik siswa kelas eksperimen lebih tinggi dari kelas kontrol. Hal tersebut sejalan dengan penelitian Brinson (2015) yang menyatakan siswa yang melakukan praktikum berbasis virtual kemudian dihadapkan dengan praktikum riil dapat melakukan praktikum dengan lebih baik dibandingkan dengan siswa yang hanya melakukan praktikum yang sama di laboratorium. Siswa kelas eksperimen lebih terampil dalam melakukan praktikum dan bisa lebih fokus dalam proses praktikum karena terlebih dahulu telah melakukan praktikum pada aplikasi virtual laboratory disertai demonstrasi karena Steinbach (2002) menyatakan bahwa proses pengetahuan akan mudah terlupakan jika siswa hanya mendapatkan melalui lisan. Adanya virtual laboratory dan demonstrasi menjadikan siswa memiliki pandangan awal terhadap praktikum di laboratorium riil dan penggunaan alat-alat secara nyata sehingga dapat menggunakannya dengan baik dan benar. Hal ini sesuai dengan penelitian Tatli dan Ayas (2010) bahwa siswa dalam penggunaan virtual laboratory lebih bisa fokus dalam proses eksperimen tanpa memikirkan kondisi bahan dan alat seperti pada praktikum riil, selain itu siswa juga dapat mencoba kembali demonstrasi yang belum mereka pahami atau sebagai sarana dalam mengulas kembali pelajaran. Namun demonstrasi yang dilakukan oleh guru di kelas eksperimen tidak selengkap demonstrasi yang dilakukan di kelas kontrol, karena demonstrasi di kelas eksperimen dimaksudkan agar siswa kelas 
eksperimen dapat menguasai penggunaan alat-alat secara nyata.

Hasil belajar psikomotorik yang dinilai ada lima aspek yang terbagi dalam tiga tahap praktikum dari tahap awal-akhir, lima aspek psikomotorik tersebut yaitu perencanaan kegiatan praktikum, persiapan alat dan bahan praktikum yang akan digunakan, proses pelaksanaan kegiatan praktikum, kebersihan alat dan tempat kerja praktikum, dan penyimpulan hasil praktikum. Perbandingan rata-rata skor tiap aspek psikomotorik antara kelas eksperimen dan kelas kontrol disajikan pada Gambar 2.

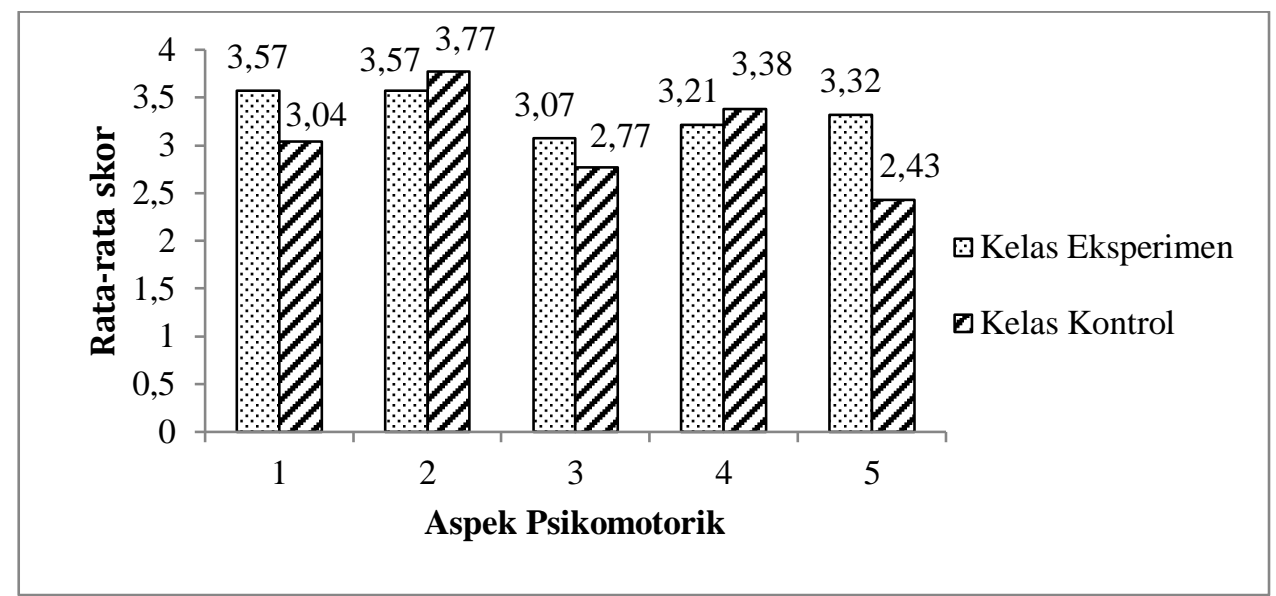

Gambar 2. Perbandingan rata-rata skor tiap aspek psikomotorik

Keterangan:

$1=$ perencanaan kegiatan praktikum

2 = persiapan alat dan bahan praktikum yang akan digunakan

3 = proses pelaksanaan kegiatan praktikum

$4=$ kebersihan alat dan tempat kerja praktikum

$5=$ penyimpulan hasil praktikum.

Berdasarkan Gambar 2 menunjukkan bahwa semua aspek psikomotorik yang dinilai kelas eksperimen memiliki skor yang lebih tinggi dari kelas kontrol, kecuali pada aspek persiapan alat dan bahan praktikum yang akan digunakan dan kebersihan alat dan tempat kerja praktikum. Aspek persiapan alat dan bahan praktikum yang akan digunakan, kelas kontrol dan kelas eksperimen berada pada kategori sangat baik namun kelas kontrol memiliki skor lebih tinggi dari kelas eksperimen, hal tersebut karena kelas kontrol diberikan demonstrasi secara lengkap sehingga kelas kontrol lebih familiar dengan alat dan bahan yang akan mereka gunakan. Selain aspek tersebut, aspek kebersihan alat dan tempat kerja praktikum pada kelas kontrol memiliki skor yang lebih tinggi dari kelas eksperimen. Hal tersebut karena kelas kontrol menghadapi bahan-bahan praktikum yang 
nyata saat demonstrasi sehingga mengerti dalam mengelola zat sisa hasil demonstrasi yang dilakukan guru sebab pada saat membersihkan hasil demonstrasi, guru juga menjelaskan perlakuan pada zat sisa praktikum.

Keterampilan Berpikir Kritis (KBK) dari hasil pretest dianalisis menggunakan uji normalitas, uji kesamaan dua varian, dan uji dua rata-rata (uji dua pihak). Hasil analisis terhadap nilai pretest menunjukkan data berdistribusi normal, kedua kelas memiliki varians yang berbeda sehingga rumus untuk uji dua rata-rata menggunakan rumus $t$, dan rata-rata nilai pretest hasil belajar kognitif kelas eksperimen sama dengan kelas kontrol. Hasil KBK posttest dianalisis menggunakan uji normalitas, uji kesamaan dua varian, uji dua rata-rata (uji satu pihak kanan), uji pengaruh antar variabel, dan penentuan koefisien determinasi. Perbandingan kategori keterampilan berpikir kritis posttest antara kelas eksperimen dan kelas kontrol disajikan pada Tabel 3.

Tabel 3. Perbandingan kategori keterampilan berpikir kritis posttest

\begin{tabular}{|c|c|c|c|c|c|}
\hline \multirow{2}{*}{ Kelas } & \multicolumn{4}{|c|}{ Kategori } & \multirow{2}{*}{$\begin{array}{l}\text { Jumlah } \\
\text { Siswa }\end{array}$} \\
\hline & Sangat Kritis & Kritis & Kurang Kritis & Tidak Kritis & \\
\hline Eksperimen & 8 & 19 & 1 & 0 & 28 \\
\hline Kontrol & 0 & 12 & 16 & 0 & 28 \\
\hline
\end{tabular}

Hasil pada Tabel 3 menunjukkan bahwa keterampilan berpikir kritis kelas eksperimen lebih baik dari kelas kontrol. Kelas eksperimen mencapai 28,57\% siswa dengan kategori sangat kritis, 67,86\% siswa dengan kategori kritis, dan 3,57\% siswa dengan kategori kurang kritis. Kelas kontrol mencapai 42,86\% siswa kategori kritis, dan $57,14 \%$ siswa kategori kurang kritis. Berdasarkan uraian tersebut disimpulkan bahwa keterampilan berpikir kritis siswa kelas eksperimen lebih baik dari kelas kontrol. Hal tersebut sejalan dengan hasil penelitian Permana, dkk (2016) bahwa virtual laboratory mengharuskan siswa untuk melakukan kegiatan praktikum secara virtual sehingga keterampilan berpikir kritis peserta didik akan terlatih.

Hasil analisis hasil KBK posttest menunjukkan data berdistribusi normal. Uji kesamaan dua varian menunjukkan kedua kelas memiliki varians yang tidak berbeda sehingga untuk uji dua rata-rata (uji satu pihak) dilakukan menggunakan rumus t. Pada 
uji dua rata-rata diperoleh $t_{\text {hitung }}(5,919)>t_{\text {tabel }}(1,680)$, artinya $\mathrm{H}_{0}$ ditolak sehingga dapat disimpulkan rata-rata skor KBK posttest kelas eksperimen lebih baik kelas kontrol. Uji pengaruh antar variabel diperoleh rb sebesar 0,453 sehingga koefisien determinasi yang menunjukkan besarnya kontribusi virtual laboratory terhadap KBK sebesar 20,54\%.

Indikator KBK yang diukur saat posttest ada enam indikator yaitu Identify the Issue/Position, Support Source, Analysis, Contradictory evidence, Personal bias or assumptions, dan Describe conclusions. Perbandingan rata-rata skor setiap indikator antara kelas eksperimen dan kelas kontrol disajikan pada Tabel 4.

Tabel 4. Perbandingan rata-rata skor indikator KBK posttest

\begin{tabular}{clcc}
\hline \multirow{2}{*}{ No. } & \multicolumn{1}{|}{ Indikator KBK } & \multicolumn{2}{c}{ Rata-rata Skor } \\
\cline { 3 - 4 } & Identify the Issue/Position & 3,06 & Kelas Eksperimen \\
2 & Support Source & 3,04 & 2,58 \\
3 & Analysis & 2,64 & 2,02 \\
4 & Contradictory evidence & 2,32 & 2,42 \\
5 & Personal bias or assumptions & 3,25 & 1,38 \\
6 & Describe conclusions & 2,55 & 1,96 \\
\hline
\end{tabular}

Hasil pada Tabel 4 menunjukkan bahwa semua indikator KBK posttest kelas eksperimen lebih tinggi dari kelas kontrol. Adanya aplikasi virtual laboratory siswa dapat dengan mudah membuktikan teori yang mereka dapatkan pada pembelajaran larutan penyangga melalui aplikasi tersebut tanpa harus menyediakan alat dan bahan seperti praktikum riil, virtual laboratory setara dengan persepsi siswa pada laboratorium riil sehingga dapat membantu logika siswa pada laboratorium riil (Polly et al., 2014). Tatli dan Ayas (2010) menyimpulkan dalam penelitiannya bahwa siswa dalam penggunaan virtual laboratory dapat mencoba kembali demonstrasi yang belum mereka pahami atau sebagai sarana dalam mengulas kembali pelajaran. Selain itu, kegiatan simulasi praktikum dapat membantu pemahaman siswa terhadap materi yang diajarkan di kelas yang berdampak pada keterampilan berpikir siswa juga terlatih dengan membandingkan teori yang diperoleh dengan hasil praktikum. Tüysüz (2010) menyatakan lingkungan belajar dengan menggunakan animasi dan simulasi memberikan siswa untuk membangun dan memahami konsep yang sulit menjadi lebih mudah. 


\section{KESIMPULAN}

Berdasarkan penelitian dan pembahasan dapat disimpulkan: (1) aplikasi virtual laboratory berkontribusi sebesar $14,57 \%$ terhadap hasil belajar siswa pada pembelajaran guided-inquiry materi larutan penyangga, (2) aplikasi virtual laboratory berkontribusi sebesar 20,54\% terhadap keterampilan berpikir kritis siswa pada pembelajaran guidedinquiry materi larutan penyangga. Saran yang dapat diberikan terkait penelitian ini yaitu meskipun penelitian ini mendukung bahwa penggunaan virtual laboratory berdampak positif terhadap hasil belajar dan keterampilan berpikir kritis namun peneliti tidak mengklaim bahwa virtual laboratory lebih efektif daripada praktikum riil. Virtual laboratory hanya bisa dijadikan solusi jika praktikum riil tidak memungkinkan untuk dilakukan.

\section{REFERENSI}

Abidin. Y. (2014). Desain Sistem Pembelajaran dalam Konteks Kurikulum 2013. Bandung: Refika Aditama.

Anisah, E., Martini, S., \& Subroto T. (2013). Keefektifan virtual laboratory terhadap hasil belajar siswa materi larutan penyangga dan hidrolisis. Chemistry In Education. 2(1), $1-6$.

Așiksoy, G., \& Islek, D. (2017). The Impact of the virtual laboratory on students' attitudes in a general physics laboratory. Internasional Journal of Online and Biomedical Engineering. 13(4), 20-28. doi: 10.3991/ijoe.v13i04.6811.

Brinson, J.R. (2015). Learning outcome achievemen in non-traditional (virtual and remote) versus traditional (hand-on) laboratories: A review of the empirical research. $\begin{array}{lllll}\text { Computers \& } \quad \text { Education. 218-237. doi: } & \end{array}$ https://doi.org/10.1016/j.compedu.2015.07.003.

Budiarti, S., Nuswowati, M., \& Cahyono, E. (2016). Guided inquiry berbantuan e-modul untuk meningkatkan keterampilan berpikir kritis. Journal of Innovative Science Education. 5(2), 144-151.

Falahudin, I., Wigati, I., \& Pujiastuti, A. (2016). Pengaruh model pembelajaran inkuiri terbimbing terhadap kemampuan berpikir kritis siswa pada pembelajaran materi pengelolaan lingkungan di SMP Negeri 2 Tanjung Lago, Kabupaten Banyuasin. Jurnal Bioilmi. 2(2), 92-101.

Harrison, T.G., Shallcross, D.E., Heslop,W.J., Eastman J.R., \& Baldwin, A.,J. (2009). Transferring best practice from undergraduate practical teaching to secondary schools: The dynamic laboratory manual. Acta Didactica Napocensia. 2(1), 1-8. 
Oktavianti, E., \& Arief A. (2016). Pengaruh model pembelajaran inkuiri dengan eksperimen virtual Mc Graw Hill pada pokok bahasan hukum newton tentang gravitasi terhadap hasil belajar siswa kelas XI SMA Negeri 3 Bangkalan. Jurnal Inovasi Pendidikan Fisika (JIPF). 5(2), 69-71.

Permana, N. A., Widiatmoko, A., \& Taufiq, M. (2016). Pengaruh virtual laboratory berbasis flash animation terhadap pemahaman konsep dan keterampilan berpikir kritis peserta didik tema optik kelas VIII SMP. Unnes Science Education Journal. 5(3), 1354-1365.

Polly, P., Marcus, N., Maguire, D., Belinson, Z \& Velan, G.M. (2014). Evaluation of an adaptive virtual laboratory environment using Western Blotting for diagnosis of disease. BMC Medical Education, 14(2), 1-9. doi: 10.1186/1472-6920-14-222.

Puspendik. 2019. Laporan Hasil Ujian Nasional SMP/ SMA/ SMK Tahun Pelajaran 2018/2019. Tersedia di http://puspendik.kemdikbud.go.id/hasil-un/2019 [diakses 1208-2019].

Simbolon, D.H., \& Sahyar. (2015). Pengaruh model pembelajaran inkuiri terbimbing berbasis eksperimen riil dan laboratorium virtual terhadap hasil belajar fisika siswa. Jurnal Pendidikan dan Kebudayaan. 21(3), 299-315.

Steinbach, R. (2002). Successful Lifelong Learning. Alih Bahasa: Kumala Insiwi Suryo. Jakarta: PPM.

Suhada, H. (2017). Model pembelajaran inquiry dan kemampuan berpikir kritis terhadap keterampilan proses sains siswa kelas V pada mate pelajaran IPA. Jurnal Pendidikan Dasar. 8(2), 13-24.

Tatli, Z., \& Ayas, A. (2013). Effect of virtual chemistry laboratory on students' achievement. Journal of Educational Technology and Society. 16(1), 159-170.

Tüysüz. C. (2010). The effect of the virtual laboratory on students' achievement and attitude in chemistry. International Online Journal of Educational Sciences. 2(1), 3753.

Wasitohadi, Sudarsono, F.X., \& Zamroni. (2014). Evaluasi implementasi paradigma baru pendidikan pascareformasi pada jenjang SD di kota Salatiga. Jurnal Pembangunan Pendidikan: Fondasi dan Aplikasi. 2(2), 196-209.

Widyaningrum, R., Sarwanto, \& Puguh. (2014). Pengembangan modul berorientasi POE (Predict, Observe, Explain) pada materi pencemaran untuk meningkatkan hasil belajar siswa. Jurnal Inkuiri. 3(2): 97-106. 